(C) 2016

Миколайко В. П., кандидат сільськогосподарських наук

Уманський національний університет садівництва

\title{
ОСОБЛИВОСТІ РОСТУ ТА РОЗВИТКУ НАСІННИКІВ ЦИКОРІЮ КОРЕНЕПЛІДНОГО ЗАЛЕЖНО ВІД МІНЕРАЛЬНОГО ЖИВЛЕННЯ
}

\author{
Рецензент - доктор сільськогосподарських наук, професор В. В. Поліщук
}

Висвітлено результати досліджень впливу мінерального живлення на приживлюваність коренеплодів, густоту рослин у фазу повних сходів, висоту рослин $i$ кількість пагонів. Встановлено, щзо застосування комплексу агрозаходів забезпечило високу приживлюваність коренеплодів, яка варіювала від 89,4 до 93,8\%. Висока приживлюваність коренеплодів забезпечила формування оптимальної густоти насінників, яка наближена до планової. З'ясовано, щуо приріст висоти рослин иикорію коренеплідного залежав як від мінеральних добрив, схем їх садіння, так $i$ від краплинного зрошення. Встановлено, щзо застосування добрив, і особливо спільно азотних $i$ калійних $N_{45} K_{70}$, забезпечило найбільший приріст висоти рослин та формування пагонів першого $i$ другого порядку як $y$ контролі - без поливу, так $i$ в умовах краплинного зрошення.

Ключові слова: ичкорій коренеплідний, добрива, приживлюваність, схема садіння, густота рослин, висота рослин, зрошення.

Постановка проблеми. Однією з високопродуктивних культур різнобічного використання $€$ цикорій коренеплідний (Cichorium intybus L.) цінна лікарська, харчова та кормова рослина. Поряд з вирощуванням інших технічних високорентабельних сільськогосподарських культур цикорій є економічно вигідною культурою, сировина якої використовується в харчовій та фармакологічній промисловості й інших галузях виробництва $[5,6]$. Під час розробки системи удобрення сільськогосподарських культур має бути тонкий і правильний підхід в умовах теперішнього зниження природної родючості грунтів та високого екологічного навантаження на них. Одним із головних завдань в рослинництві $€$ ефективне застосування мінеральних добрив. Науково обгрунтована система удобрення має забезпечити високу урожайність сільськогосподарських культур 3 оптимальними показниками якості продукції, збереження або диференційованого підвищення родючості грунту за дотримання екологічної безпеки [3]. Цикорій коренеплідний чутливий до нестачі елементів живлення і без достатнього забезпечення рослин необхідними елементами мінерального живлення в оптимальні періоди високий врожай отримати практично неможливо.

Аналіз останніх досліджень і публікацій, у яких започатковано розв'язання проблеми. Ефективність мінеральних добрив залежить як від співвідношення елементів живлення, так і від форм добрив. За однієї і тієї ж кількості діючої речовини різні форми добрив забезпечують різні результати, що зумовлено фізіологічними особливостями рослин. Установлено, що 3 фосфорних добрив для цикорію коренеплідного на дерново-підзолистих і сірих лісових грунтах $є$ суперфосфат. Доброю формою азотних добрив на всіх видах грунтів $\epsilon$ сечовина та селітра. 3 калійних добрив кращими для цикорію $є$ безхлорні сполуки. Оптимальним співвідношенням NPK є 2:1:4, що позитивно впливає на урожайність та хімікотехнологічні властивості коренеплодів цикорію [2].

Водночас нераціональне використання мінеральних добрив за сьогоднішніх дуже високих ринкових цін на них може суттєво знизити рівень рентабельності виробництва, що може призвести до збитковості культури. Тому під час розрахунку доз добрив під цикорій ми враховували потребу насінників в елементах живлення для формування відповідної урожайності, вміст доступних для рослин поживних речовин у грунті та в добривах.

Дослідження Н. С. Авдоніна [1] показали, що фосфорні добрива використовуються рослиною цикорію в початковій фазі свого росту і розвитку, калійні - на третьому місяці вегетації, а азот протягом усього вегетаційного періоду. За даними В. В. Лапи [4] в разі збільшення доз азотних добрив збільшується винос азоту, в меншій мірі - калію і практично не змінюється винос фосфору. У період вегетації цикорій використовує 3 грунту $31 \%$ фосфору та $54 \%$ калію, водночас використання калію збільшується за спільного використання його з фосфором. Тобто, рослини цикорію коренеплідного споживають фосфору менше, ніж азоту і калію.

Мета дослідження - вивчити вплив мінерального живлення на приживлюваність коренеплодів, густоту рослин у фазу повних сходів залеж- 


\section{СІЛЬСЬКЕ ГОСПОДАРСТВО. РОСЛИННИЦТВО}

но від схем садіння коренеплодів в умовах краплинного зрошення та біометричні показники, зокрема висоту рослин і кількість пагонів.

Методика дослідження. Вихідним матеріалом для дослідження були селекційні номери та сорти цикорію коренеплідного, які в результаті селекційної роботи було отримано на Уманській дослідно-селекційній станції Інституту біоенергетичних культур і цукрових буряків НААН. Експериментальні дослідження виконано на цій же станції протягом 2012-2015 рр.

Грунти Уманської дослідно-селекційної станції характеризуються досить високим вмістом рухомих сполук фосфору - 96,3 мг/кг та обмінного калію - 62,5 мг/кг (за методом Чирикова) i низьким вмістом азоту легкогідролізованих сполук - 12,7 мг/кг грунту (за методом Корнфільда). Враховуючи результати досліджень [1, 2, 4] та забезпеченість грунту елементами мінерального живлення дослідних ділянок, схемою передбачено внесення лише азотних та калійних добрив навесні перед садінням коренеплодів як окремо, так i разом. Статистичний обрахунок даних проводили методом дисперсійного аналізу за Фішером [7].

Результати досліджень. Серед основних напрямів підвищення продуктивності цикорію коренеплідного є створення сприятливих умов для прояву високої потенційної продуктивності сортів. Весь комплекс агротехнологічних заходів повинен бути направлений на забезпечення оптимальних умов проходження фізіологічних процесів, які визначають високу продуктивність рослин.

Одним із важливих показників, який впливає на густоту рослин i відповідно на продуктивність насінників $є$ приживлюваність коренеплодів. Висока приживлюваність коренеплодів разом із грунтово-кліматичними й агротехнічними умовами забезпечують оптимальні умови для росту і розвитку рослин цикорію коренеплідного та високу урожайність і якість насіння. Приживлюваність коренеплодів в усіх варіантах була високою і становила від 89,4 до 93,8 \% (табл. 1).

Істотної різниці 3 приживлюваності коренеплодів залежно від мінерального живлення не виявлено як у контролі - без зрошення, так і в умовах краплинного зрошення. За краплинного зрошення приживлюваність була істотно вищою, ніж у контролі за обох схем садіння висадків незалежно від рівня мінерального живлення. Так, якщо в контролі - без зрошення і без добрив за схеми садіння коренеплодів $60 \times 45$ см - приживлюваність становила 90,7\%, то за умов краплинного зрошення за цієї ж схеми садіння вона збільшилася на 2,5 і 2,9 \% і становила відповідно
- 93,2 та 93,6 \% ( IIP $_{05}$ зрошення $\left.=1,5 \%\right)$. Аналогічне підвищення відсотка приживлюваності коренеплодів було і за схеми садіння $45 \times 25 \mathrm{~cm}$. За зменшення площі живлення насінників (схема садіння $45 \times 25$ см) спостерігалося значне зниження відсотку приживлюваності, порівняно зі схемою садіння $60 \times 45$ см. Так, у контролі - без зрошення і без добрив за схеми садіння $60 \times 45 \mathrm{~cm}$ приживлюваність була 90,7 \%, а за схеми садіння $45 \times 25$ см вона зменшилася на $1,2 \%$. У контролі за використання добрив приживлюваність коренеплодів за схеми садіння $45 \times 25$ см зменшилася на 0,9-1,7\%, порівняно зі схемою садіння $60 \times 45 \mathrm{~cm}\left(\mathrm{HIP}_{05}\right.$ схеми садіння $\left.=0,4 \%\right)$. Аналогічне зниження відсотку приживлюваності коренеплодів зазначено і в умовах краплинного зрошення.

Під час опрацювання даних залежності між приживлюваністю рослин цикорію коренеплідного та агротехнічними заходами, що вивчали, важливо 3'ясувати вплив кожного заходу i, особливо добрив. Так, за результатами наших досліджень встановлено, що добрива не мали істотного впливу на приживлюваність рослин. Основний вплив на приживлюваність рослин мав діапазон краплинне зрошення (частка впливу становила $67,3 \%$ ) та схеми садіння висадків - частка впливу була меншою і становила 9,6 \% (рис. 1), що свідчить про те, що за вирощування насіння цикорію коренеплідного в умовах краплинного зрошення можна досягнути високого відсотку приживлюваності рослин. Частка впливу добрив була низькою - 0,3\%.

Висока приживлюваність коренеплодів забезпечила формування оптимальної густоти насінників, яка наближена до планової. Був створений однорідний фон для дослідження ефективності мінерального живлення, схем садіння та краплинного зрошення на біометричні показники насінників, процес квіткоутворення, фотосинтетичний потенціал та формування і дозрівання насіння. Густота рослин у фазу повних сходів у контролі - без добрив становила за схеми садіння 60×45 см 33,6 тис./га, а на ділянках (контроль), де були внесені мінеральні добрива 33,5-33,7 тис./га. В умовах краплинного зрошення за цієї ж схеми садіння густота рослин варіювала від 34,5 до 34,7 тис./га.

Істотної різниці за цим показником не було. Аналогічні результати отримані за схем садіння коренеплодів $45 \times 25 \mathrm{~cm}$, але густота рослин була значно вищою, ніж за схеми садіння $60 \times 45$ см, що зумовлено більшою кількістю висаджених коренеплодів - загущеним садінням згідно зі схемою досліду. 
СІЛЬСЬКЕ ГОСПОДАРСТВО. РОСЛИННИЦТВО

\section{1. Приживлюваність коренеплодів та їх густота рослин у фазу повних сходів} в умовах краплинного зрошення (середнє за 2012-2015 рр.)

\begin{tabular}{|c|c|c|c|c|}
\hline \multicolumn{3}{|c|}{ Варіант } & \multirow{2}{*}{$\begin{array}{l}\text { Приживлю- } \\
\text { ваність рос- } \\
\text { лин, \% } \\
\end{array}$} & \multirow{2}{*}{$\begin{array}{c}\text { Густота рослин } \\
\text { у фазу повних } \\
\text { сходів } \\
\end{array}$} \\
\hline зрошення & схема садіння & добрива & & \\
\hline \multirow{8}{*}{$\begin{array}{c}\text { Контроль } \\
\text { (без зрошення) }\end{array}$} & \multirow{4}{*}{$60 \times 45$} & Без добрив & 90,7 & 33,6 \\
\hline & & $\mathrm{N}_{45}$ & 91,1 & 33,7 \\
\hline & & $\mathrm{K}_{70}$ & 91,0 & 33,7 \\
\hline & & $\mathrm{N}_{45} \mathrm{~K}_{70}$ & 90,6 & 33,5 \\
\hline & \multirow{4}{*}{$45 \times 25$} & Без добрив & 89,5 & 79,6 \\
\hline & & $\mathrm{N}_{45}$ & 89,4 & 79,5 \\
\hline & & $\mathrm{K}_{70}$ & 89,5 & 79,6 \\
\hline & & $\mathrm{N}_{45} \mathrm{~K}_{70}$ & 89,7 & 79,7 \\
\hline \multirow{8}{*}{$\begin{array}{l}\text { Зрошення. Вологість } \\
\text { грунту } 60 \text { \% від НВ } \\
\text { упродовж вегетації }\end{array}$} & \multirow{4}{*}{$60 \times 45$} & Без добрив & 93,2 & 34,5 \\
\hline & & $\mathrm{N}_{45}$ & 93,1 & 34,6 \\
\hline & & $\mathrm{K}_{70}$ & 93,5 & 34,6 \\
\hline & & $\mathrm{N}_{45} \mathrm{~K}_{70}$ & 93,8 & 34,7 \\
\hline & \multirow{4}{*}{$45 \times 25$} & Без добрив & 92,3 & 80,4 \\
\hline & & $\mathrm{N}_{45}$ & 92,4 & 80,5 \\
\hline & & $\mathrm{K}_{70}$ & 92,4 & 80,5 \\
\hline & & $\mathrm{N}_{45} \mathrm{~K}_{70}$ & 92,3 & 80,7 \\
\hline \multirow{8}{*}{$\begin{array}{c}\text { Зрошення. Вологість } \\
\text { грунту до фази цвітіння } \\
60 \% \text { у у фазу цвітіння до } \\
\text { збирання } 80 \text { \% від НВ }\end{array}$} & \multirow{4}{*}{$60 \times 45$} & Без добрив & 93,6 & 34,6 \\
\hline & & $\mathrm{N}_{45}$ & 93,4 & 34,6 \\
\hline & & $\mathrm{K}_{70}$ & 93,8 & 34,7 \\
\hline & & $\mathrm{N}_{45} \mathrm{~K}_{70}$ & 93,7 & 34,7 \\
\hline & \multirow{4}{*}{$45 \times 25$} & Без добрив & 92,9 & 80,3 \\
\hline & & $\mathrm{N}_{45}$ & 92,7 & 80,4 \\
\hline & & $\mathrm{K}_{70}$ & 92,7 & 80,4 \\
\hline & & $\mathrm{N}_{45} \mathrm{~K}_{70}$ & 93,4 & 80,5 \\
\hline \multicolumn{3}{|c|}{ HIP 05 зрошення } & 1,5 & 6,7 \\
\hline \multicolumn{3}{|c|}{$\mathrm{HIP}_{05}$ схеми садіння } & 0,4 & 1,9 \\
\hline \multicolumn{3}{|c|}{ HIP 05 добрива } & 1,1 & 4,7 \\
\hline
\end{tabular}

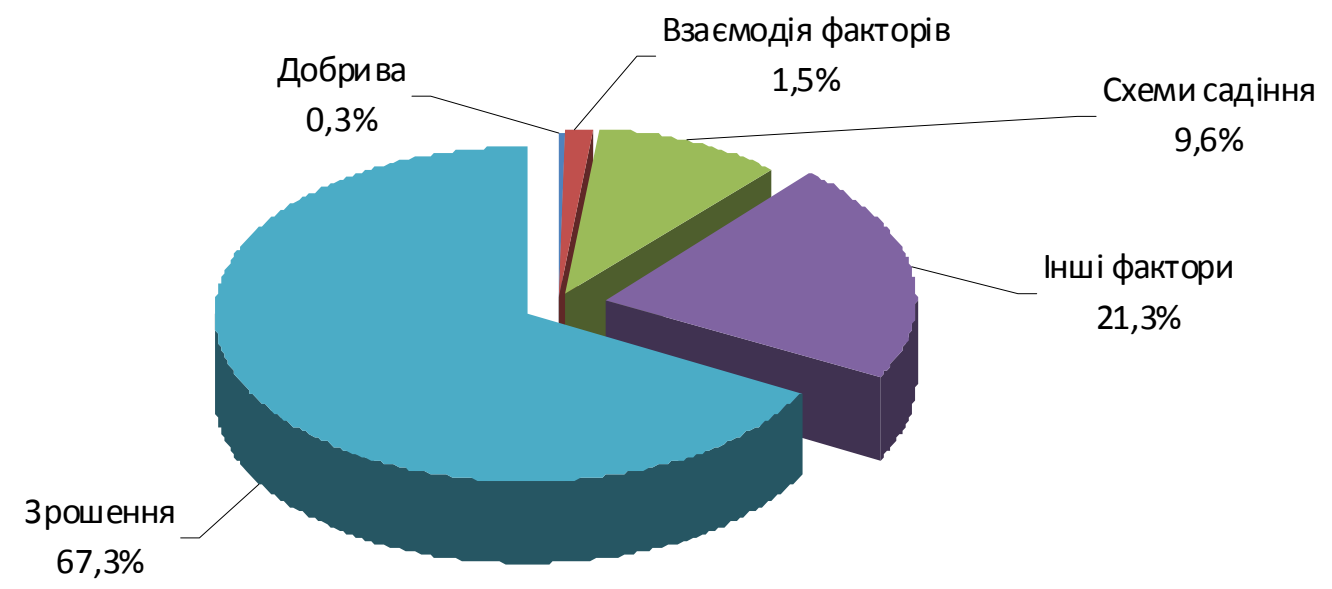

Рис. 1. Частка впливу факторів на приживлюваність рослин залежно від агрозаходів 
2. Біометричні показники насінників залежно від агротехнічних заходів їх вирощування (середнс за 2012-2015 рp.)

\begin{tabular}{|c|c|c|c|c|c|c|c|}
\hline \multicolumn{3}{|c|}{ Варіант } & \multirow{2}{*}{ 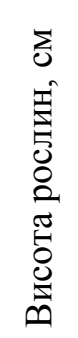 } & \multicolumn{4}{|c|}{ Кількість пагонів, шт. } \\
\hline зрошення & схема садіння & добрива & & $\begin{array}{l}0 \\
0 \\
0 \\
0 \\
0\end{array}$ & 崖 & 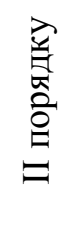 & 密 \\
\hline \multirow{8}{*}{$\begin{array}{c}\text { Контроль } \\
\text { (без зрошення) }\end{array}$} & \multirow{4}{*}{$60 \times 45$} & Без добрив & 147 & 29 & 9 & 20 & 0 \\
\hline & & $\mathrm{N}_{45}$ & 158 & 34 & 10 & 22 & 2 \\
\hline & & $\mathrm{K}_{70}$ & 147 & 29 & 8 & 21 & 0 \\
\hline & & $\mathrm{N}_{45} \mathrm{~K}_{70}$ & 160 & 38 & 11 & 24 & 3 \\
\hline & \multirow{4}{*}{$45 \times 25$} & Без добрив & 154 & 21 & 7 & 14 & 0 \\
\hline & & $\mathrm{N}_{45}$ & 160 & 26 & 8 & 15 & 3 \\
\hline & & $\mathrm{K}_{70}$ & 157 & 21 & 7 & 14 & 0 \\
\hline & & $\mathrm{N}_{45} \mathrm{~K}_{70}$ & 163 & 29 & 9 & 16 & 4 \\
\hline \multicolumn{3}{|c|}{ Середнє } & 156 & 28 & 9 & 18 & 2 \\
\hline \multirow{8}{*}{$\begin{array}{l}\text { Зрошення. Вологість } \\
\text { грунту } 60 \text { \% від НВ } \\
\text { упродовж вегетації }\end{array}$} & \multirow{4}{*}{$60 \times 45$} & Без добрив & 180 & 46 & 14 & 24 & 8 \\
\hline & & $\mathrm{N}_{45}$ & 188 & 51 & 16 & 26 & 9 \\
\hline & & $\mathrm{K}_{70}$ & 179 & 44 & 16 & 24 & 4 \\
\hline & & $\mathrm{N}_{45} \mathrm{~K}_{70}$ & 192 & 54 & 18 & 27 & 9 \\
\hline & \multirow{4}{*}{$45 \times 25$} & Без добрив & 184 & 33 & 13 & 20 & 0 \\
\hline & & $\mathrm{N}_{45}$ & 191 & 42 & 14 & 22 & 6 \\
\hline & & $\mathrm{K}_{70}$ & 182 & 31 & 12 & 19 & 0 \\
\hline & & $\mathrm{N}_{45} \mathrm{~K}_{70}$ & 194 & 46 & 15 & 23 & 8 \\
\hline \multicolumn{3}{|c|}{ Середнє } & 186 & 43 & 15 & 23 & 6 \\
\hline \multirow{8}{*}{$\begin{array}{c}\text { Зрошення. Вологість } \\
\text { грунту до фази цвітіння } \\
60 \text { \%, у фазу цвітіння до } \\
\text { збирання } 80 \text { \% від НВ }\end{array}$} & \multirow{4}{*}{$60 \times 45$} & Без добрив & 182 & 37 & 14 & 22 & 1 \\
\hline & & $\mathrm{N}_{45}$ & 186 & 42 & 15 & 23 & 4 \\
\hline & & $\mathrm{K}_{70}$ & 180 & 34 & 14 & 20 & 0 \\
\hline & & $\mathrm{N}_{45} \mathrm{~K}_{70}$ & 190 & 47 & 16 & 26 & 5 \\
\hline & \multirow{4}{*}{$45 \times 25$} & Без добрив & 187 & 34 & 16 & 17 & 1 \\
\hline & & $\mathrm{N}_{45}$ & 191 & 36 & 16 & 18 & 2 \\
\hline & & $\mathrm{K}_{70}$ & 186 & 31 & 15 & 16 & 0 \\
\hline & & $\mathrm{N}_{45} \mathrm{~K}_{70}$ & 198 & 40 & 18 & 20 & 2 \\
\hline \multicolumn{3}{|c|}{ Середнє } & 188 & 38 & 16 & 20 & 2 \\
\hline \multicolumn{3}{|c|}{ HIP 05 зрошення } & 5,1 & & & & \\
\hline \multirow{2}{*}{\multicolumn{3}{|c|}{$\begin{array}{l}\text { HIP } 05 \text { схеми садіння } \\
\text { НIP } 05 \text { добрива }\end{array}$}} & 1,5 & & & & \\
\hline & & & 3,6 & & & & \\
\hline
\end{tabular}

Інтенсивність наростання наземної маси в онтогенезі рослин залежить не лише від погодних умов періоду вегетації, а і від агротехнічних способів їх вирощування. Дослідженнями з'ясовано, що приріст висоти рослин цикорію коренеплідного залежав як від схем їх садіння, мінеральних добрив, так і від краплинного зрошення (табл. 2).

Найістотніший приріст висоти рослин та утворення пагонів першого і другого порядків, на яких формується насіння, забезпечило краплинне зрошення. У середньому по дослідах за краплинного зрошення насінники були вищими на 30-32 см, а пагонів першого і другого порядку було більше на 5-7 шт./рослині, порівняно з контролем - без зрошення. Водночас у випадку різного рівня забезпечення насінників вологою істотної різниці у висоті рослин та кількості пагонів першого і другого порядку не було. Так, якщо за вологості грунту на рівні $60 \%$ від НВ упродовж усього вегетаційного періоду висота насінників становила 186 см, то за вологості на рівні $60 \%$ до фази цвітіння і $80 \%$ у міжфазний період вона була 188 см. Це зумовлено біологією рослин. 


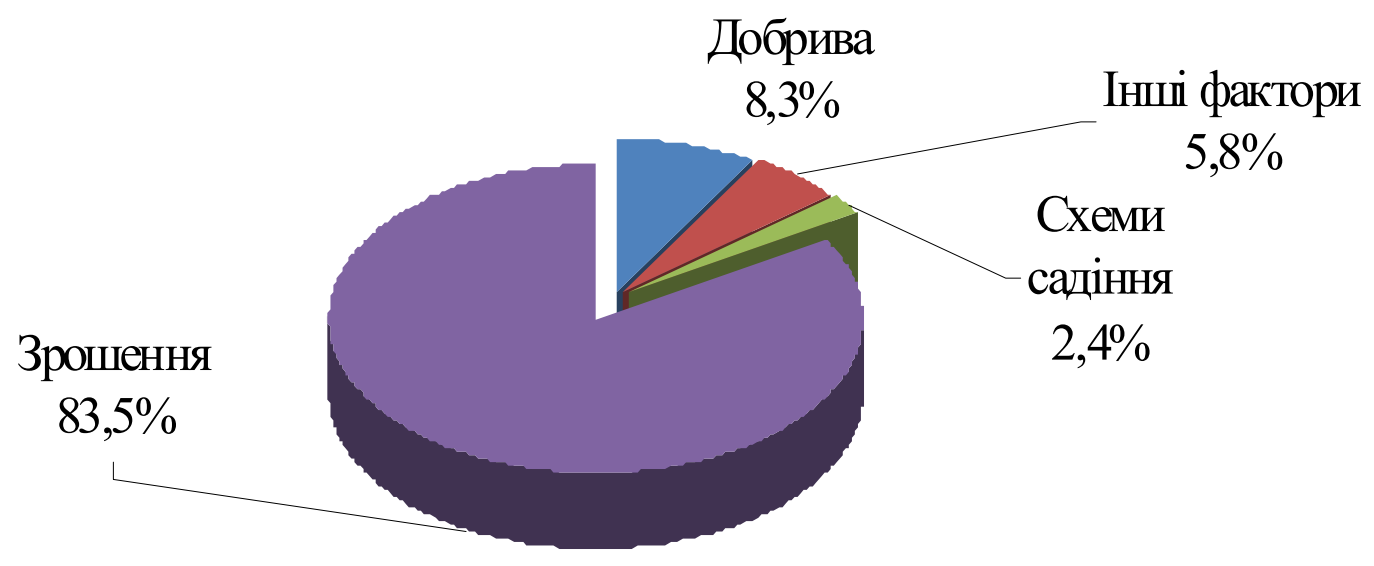

\section{Рис. 2. Частка впливу факторів на висоту насінників цикорію коренеплідного (середнс за 2012-2015 pp.)}

Адже інтенсивний приріст наземної маси відбувається до початку цвітіння, а у міжфазний період «цвітіння-дозрівання насіння» поживні речовини витрачаються рослиною переважно на формування генеративних органів і формування насіння, а не на приріст наземної маси.

Застосування добрив, і особливо спільно азотних i калійних $\mathrm{N}_{45} \mathrm{~K}_{70}$, забезпечило найбільший приріст висоти рослин та формування пагонів першого і другого порядку як у контролі - без поливу, так і в умовах краплинного зрошення. В умовах краплинного зрошення насінники істотно були вищими і на них більше було пагонів першого та другого порядку в усіх варіантах із добривами, порівняно з контролем - без добрив та 3 добривами, але без зрошення. В разі застосування лише калійних добрив висота рослин та кількість на них пагонів першого і другого порядку були на рівні контролю - без добрив як без зрошення, так і $з$ його застосуванням. Застосування лише азотних добрив забезпечило приріст висоти рослин, порівняно 3 контролем - без добрив та 3 варіантом, де вносили лише калійні добрива, а також спостерігалася тенденція збільшення пагонів першого та другого порядку.

Значний приріст висоти насінників зазначено залежно від схем їх розміщення як у контролі, так і в умовах краплинного зрошення. За схеми садіння висадків $45 \times 25$ см в усіх варіантах насінники були істотно вищими, ніж за схеми са-

\section{БІБЛІОГРАФІЯ}

1. Авдонин Н. С. Цикорий / Н. С. Авдонин. M., 1935. - C. 34.

2. Вильчик В. А. Цикорий / В. А. Вильчик. Ярославль : Верх-Волж. кн. изд-во, 1982. - С. 38. діння $60 \times 45$ см як у контролі - без зрошення, так i в умовах краплинного зрошення. I навпаки, за зменшення площі живлення насінників (схеми садіння $45 \times 25$ см) на кожному насіннику було сформовано менше пагонів першого та другого порядку, на яких формується урожайність насіння, ніж на насінниках, які мали більшу площу живлення (схема садіння $60 \times 45 \mathrm{~cm}$ ).

Під час визначення факторів, які впливали на висоту насінників залежно від агрозаходів, встановлено, що вплив фактору «зрошення» був найбільшим і становив 83,5\% (рис. 2).

Частка впливу фактору «добрива» була меншою і становила $8,3 \%$, ще меншим був вплив фактору «схеми садіння» - 2,4 \%. Взаємодія факторів мала незначний вплив на висоту рослин.

Висновок. Застосування комплексу агрозаходів забезпечило високу приживлюваність коренеплодів, яка варіювала від 89,4 до 93,8 \%. Істотної різниці з цього показника залежно від мінерального живлення не виявлено.

Приріст висоти рослин цикорію коренеплідного залежав як від мінеральних добрив, схем їх садіння, так і від краплинного зрошення.

Встановлено, що застосування добрив, і особливо спільно азотних і калійних $\mathrm{N}_{45} \mathrm{~K}_{70}$, забезпечило найбільший приріст висоти рослин та формування пагонів першого і другого порядку, на яких формується насіння як у контролі - без поливу, так і в умовах краплинного зрошення.

3. Лапа В. В. Влияние удобрений на урожайность и качество озимого тритикале на дерновоподзолистой легкосуглинистой почве / В. В. Лапа, В. Н. Босак, Н. А. Близнюк // Агрохимия. - 2005. - 
№7. - C. 25-28.

4. Лапа В. В. Продуктивность зернового севооборота и плодородие дерново-подзолистой супесчаной почвы при различной системе применения удобрений / В. В. Лапа // Агрохимия. 2003. - №1. - C. 20-29.

5. Шичева Л. А. Ботаническое описание цикория / Л. А. Шичева // Цикорий. - М. : изд-во
ВНИИ сырья спиртовой промышленности, 1935. C. 17-25.

6. Яценко А. О. Цикорій: біологія, селекція, виробництво i переробка коренеплодів / А. О. Яценко. - Умань, 2003. - 157 с.

7. Fisher R. A. Statistical methods for research workers / R. A. Fisher. - New Delhi : Cosmo Publications, 2006. -354 p. 